\title{
CSR and Tax Aggressiveness: The Moderation Role of Risk Management
}

\author{
Ain Hajawiyah $^{1}$, Indah Fajarini Sri Wahyuningrum ${ }^{2}$, Niswah Baroroh $^{3}$, Kiswanto ${ }^{4}$, Atta Putra \\ Harjanto $^{5}$ \\ \{ainhajawiyah@mail.unnes.ac.id ${ }^{1}$ \} \\ Universitas Negeri Semarang, Indonesia ${ }^{1,2,3,4,5}$
}

\begin{abstract}
This study aims to examine the effect of CSR on tax aggressiveness of nonfinancial companies in Indonesia. This study also aims to examine the moderation role of risk management in the effect of CSR on tax aggressiveness. This study uses secondary data sourced from Indonesia Stock Exchange (IDX) and firms' website amounted to 342 firm-years covering 2013-2018. The data then processed using balanced panel regression with STATA 12 Software. The result shows that there is no significant effect of CSR on tax aggressiveness. The result also shows that risk management moderate the effect of CSR on tax aggressiveness. This study is useful for industry in making CSR reporting and tax aggressiveness strategy. This study also useful for tax authority in evaluating the risk of tax aggressiveness through CSR reporting.
\end{abstract}

Keywords: CSR, Risk Management, Tax Aggressiveness.

\section{Introduction}

Companies are not only required to provide optimum value for shareholders, but also are required to provide value added for all stakeholders, includes community and the environment. The concept of social responsibility rests on the notion that companies not only have economic and legal obligations, but also have responsibilities to society. Government through Law No. 40 of 2007 and OJK Kep-431/BL/2012 regulations require all companies listed on the Indonesia Stock Exchange (IDX) to report on corporate social activities in annual reports. CSR becomes an important thing for business organizations to realize their commitment in establishing relationships with internal and external stakeholders of the company.

Most of Indonesia's state revenue comes from taxes. There are differences in interests between the government as a tax collector and companies as taxpayers. The company tried to pay taxes as minimum as possible to maximize profits, namely tax aggressiveness.

Tax aggressiveness is an act of manipulation in reducing taxable income through tax planning, whether in the form of tax evasion or not [1]. It is feared that the act of tax aggressiveness encourage management to be opportunistic if it is done without regard to the long-term sustainability of the company [2]. Companies that carry out tax aggressiveness are companies that do not have social responsibility [3]. CSR activities can be considered as a benchmark for determining the sustainability of a company. 
The level of CSR activities varies by company. The higher the company's awareness of the importance of CSR, the company should also have a high awareness of the importance of taxes for the community. The high activity of CSR is expected to negatively affect the level of corporate tax aggressiveness. CSR is considered to represent the level of corporate awareness. Responsible CSR activities will make companies more comply with regulations by not being involved in tax aggressiveness [4][5]. CSR is negatively related to Effective Tax Rate (ETR) and positively related to tax lobbying expenditure (positively affecting tax avoidance) [6].

Previous research related to the effect of CSR on tax aggressiveness still shows different results. CSR has a negative effect on tax aggressiveness shown by the research results of Lanis and Richardson's [3], Hoi et al. [7], Lanis \& Richardson [8], Qodraturrasyid [9], Karthikeyan \& Jain [10], Shafer \& Simmons [11], and Zeng [12].

However, other studies have found that CSR has a positive effect on tax aggressiveness [13]. Other studies conclude that CSR activities have no effect on tax aggressiveness [14][15]. The company continues to carry out tax aggressiveness despite CSR, especially countries that have transactions in tax haven countries [14][15][16].

On the other hand, CSR is used to avoid company's tax obligations or to cover its opportunistic behavior in avoiding taxes. Companies that avoid tax have a higher level of CSR disclosure to maintain the legitimacy of the company's operational activities and cover the company's opportunistic behavior [17].

CSR activities is a form of responsibility, not a way to avoid company's tax obligations. Therefore, effective supervision is needed through the mechanism of Corporate Governance (CG) in the company [8]. One of the CG mechanisms that is expected to influence the relationship of CSR and tax aggressiveness is risk management. The CG mechanism through effective risk management is a way to reduce tax aggressiveness. Risk management is expected to be able to maintain the consistency of CSR activities as a form of responsibility, not as a form of tax aggressiveness because it can potentially lead to tax compliance issues [9].

Global Reporting Initiatives (GRI) [18] states that tax payments are a positive contribution to people's welfare. However, some companies have argued in their sustainability reports that tax payments reduce social welfare. Minimum tax payments increase economic development [6].

Companies may consider tax payments as a reduction in public welfare because tax payments can reduce innovation, job growth and economic development [19]. Profit institutions are more efficient than governments in allocating resources [20]. Smaller tax payments can make social benefits higher.

Previous research that show inconsistent result suggest that there are other variables that influence the relationship between CSR and tax aggressiveness. This study aims to examine the effect of CSR on tax aggressiveness and to examine the moderating effect of risk management on the effect of CSR on tax aggressiveness.

The inconsistency of the results of previous studies encouraged researchers to test a variable that might moderate the influence of CSR to Tax Aggressiveness. The object of this research is Indonesia with the intention of analyzing the differences in the research context compared to previous research and enriching the literature (different law enforcement and still developing capital markets), thus causing differences in CSR activities and tax aggressiveness.

To strengthen the development of hypotheses and analysis of the results of this study, we use corporate culture theory to examine the effect of CSR on tax aggressiveness. The study 
took a sample of companies in the non-financial industry which are listed on the Indonesia Stock Exchange with an observation year 2013-2018. Data sources used are secondary data in the form of annual reports and sustainability reports.

This study contributes to academics by adding literature about CSR, tax aggressiveness, and risk management. This study also contributes to industry in formulating CSR and tax planning strategy. For tax authority, this study could be used in evaluating the risk of tax aggressiveness through CSR activity.

The remaining section of the paper discussed about literature review and hypothesis development, methodology, result and discussion, conclusions, and suggestions.

\section{Literature Review}

This section discusses about theory, hypothesis development, and research framework used in this study.

\subsection{Corporate Culture Theory}

This theory is used to analyze the effect of CSR on tax aggressiveness. All company decisions must reflect the value of right behavior, so it results negative relationship between CSR and tax aggressiveness [21]. Companies should not be involved in activities that can have negative consequences on society.

The company carries out CSR activities for the welfare of various stakeholders including shareholders, employees, customers, suppliers, regulators, creditors, and the community. If the government is also considered as part of these stakeholders, then tax aggressiveness should be being inconsistent with CSR activities. Therefore, if corporate culture drives corporate decisions, then socially responsible companies have a low level of tax aggressiveness.

Stakeholders are those who influence or are affected by company's policies and operational activities [22]. To accommodate the interests of other stakeholders, company initiations have emerged in the form of social activities by targeting other stakeholders besides shareholders such as employees, suppliers, government, consumers, the environmental community and the community around the company carrying out its operations.

Although ethically CSR can be said to be one of the symbols of corporate ethics [22], other studies Lanis \& Richardson [23] have found that CSR is used by companies to cover up unethical actions such as corporate tax avoidance practices. But departing from corporate culture theory and the influence of CSR disclosure by companies, this study will refer to corporate culture theory as has been done by Lanis \& Richardson [8] and Bozzolan et al. [24] and $\mathrm{Col} \&$ Petal [21].

\subsection{Hypothesis Development}

Tax aggressiveness is carried out for the benefit of shareholders without considering the negative impact on other stakeholders such as government and society [25]. Tax aggressiveness is considered unethical and irresponsible by the community and other stakeholders [26]. Reputation is very important as a legitimacy strategy [27]. The company is expected to provide information on CSR activities as a voluntary disclosure for related parties to increase legitimacy through maintaining its reputation [28]. Companies are expected to be 
more careful in carrying out tax aggressiveness Lanis \& Richardson [3] to maintain their reputation.

CSR activities and the fulfillment of tax obligations are still considered large expenses for companies so that many companies doing CSR activity to carry out tax aggressiveness actions to minimize their tax obligations [16]. This action is considered socially irresponsible and unacceptable [3]. Companies that carry out CSR are considered as ethical and responsible companies so that they have a good reputation [11].

Based on corporate culture theory, corporate decisions must reflect the value of right behavior resulting in a negative relationship between CSR and tax aggressiveness [21]. Companies should not be involved in activities that can have negative consequences on society. The company carries out CSR activities for the welfare of various stakeholders including the government. Tax aggressiveness is seen as being inconsistent with CSR activities. Therefore, socially responsible companies have a low level of tax aggressiveness.

Lanis and Richardson [3] conclude that the more corporate investment in social activities, the less likely the company is to avoid tax (study in Australia). Landolf [29] and Williams (2007) concludes that when companies take tax avoidance actions, public attention will lead to these unethical actions that damage the reputation and legitimacy that the company has built with the community and the surrounding environment.

Qodraturrasyid [9] conducted a study in Indonesia and found a negative relationship between CSR activities and tax aggressiveness actions. The risk management system has a role in moderating the relationship between CSR and tax aggressiveness (strengthening negative influences).

Increased CSR activities provide legitimacy through improved reputation (van der Laan, 2009). Companies are expected to have low level tax aggressiveness to maintain their reputation [3]. Laguir et al. [30] concluded that the higher the social dimension of CSR activities, the lower the level of tax aggressiveness; the higher the economic dimension, the higher the level of tax aggressiveness. Karthikeyan \& Jain [10], Zeng [12], Lanis \& Richardson [3], Hoi et al. [7] also concluded that there is a negative relationship of CSR to tax aggressiveness.

\section{Hypothesis 1: CSR has a negative effect on tax aggressiveness}

CSR activities and tax payments are a burden on the company. Both oversight mechanisms are needed, especially the board of commissioners in carrying out its supervisory role [8]. CSR activities and tax payments can be seen as ethical actions that benefit all stakeholders [31].

The risk management system is one way to assess the fairness of methodology and assumptions in compiling accounting and taxation information. With the implementation of a comprehensive risk management system, reporting CSR activities and fulfilling tax obligations will be higher quality.

Companies with more effective risk management systems should tend not to be involved in financial reporting fraud, for example management is not being optimistic by choosing CSR based solely on income tax deduction aspects. In Indonesia, provisions relating to CSR activities as an aspect of income tax deduction are specifically regulated in PP No. 93 of 2010 concerning Deductible Donations from Gross Income. The effect of CSR activities in reducing tax aggressiveness is strengthened by the application of effective risk management. The risk management system has a role in moderating the relationship between CSR and tax 
aggressiveness (strengthening negative influences).

\section{Hypothesis 2: Risk Management moderate the effect of CSR on tax aggressiveness}

\subsection{Research Framework}

Figure 1 shows the research framework used in this study.

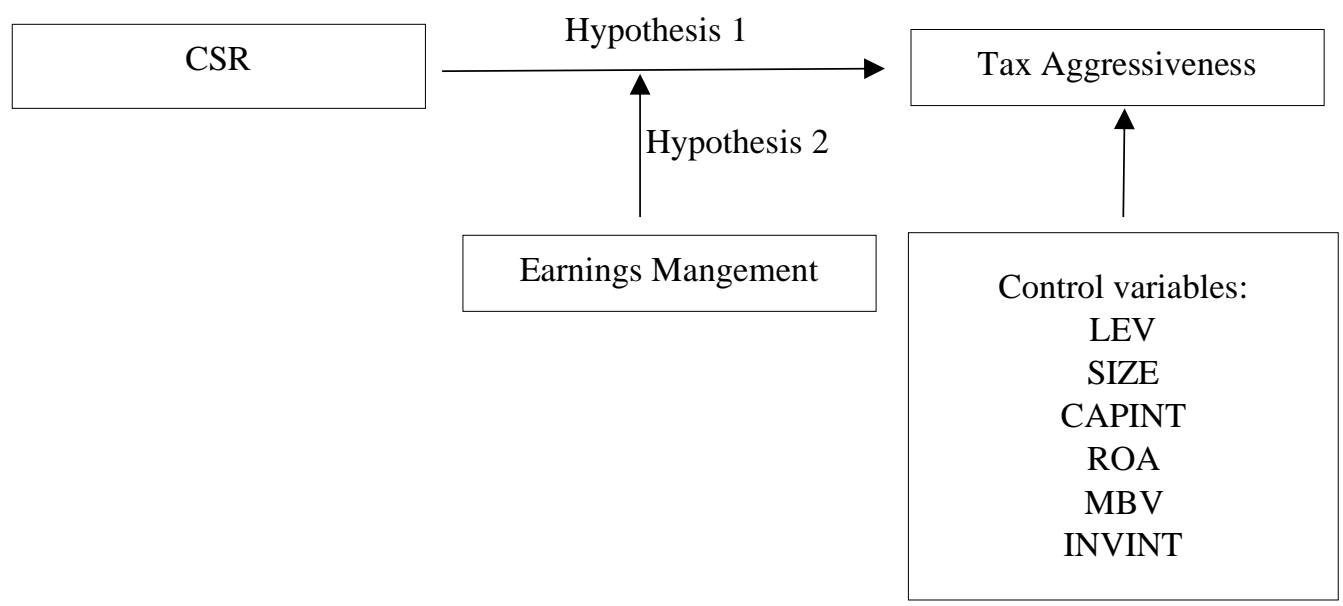

Fig. 1. Research Framework

\section{Research Methods}

This research paper uses empirical approach. The secondary data was analyzed using panel regression with STATA software. Population used in this study is non-financial firms listed in Indonesia Stock Exchange (IDX) year 2013-2018 while the samples are chosen by using some criteria (table 1). The data were collected by using documentation techniques.

Equation 1 shows the research model refers to Davis et al. [6] with adjustment in control variable:

$$
\begin{aligned}
& \operatorname{TaxAg}_{i, t}=\alpha+\beta_{1} \operatorname{CSR}_{, t}+\beta_{2} \operatorname{CSR}_{*} \mathrm{RM}_{i, t}+\beta_{3} R M_{i, t}+\beta_{4} L E V_{i, t}+\beta_{5} \operatorname{SIZE}_{i, t}+ \\
& \beta_{6} \operatorname{CAPINT}_{i, t}+\beta_{7} R O A_{i, t}+\beta_{8} M B V_{i, t}+\beta_{9} I N V I N T_{i, t}+\varepsilon_{i, t}
\end{aligned}
$$

Table 2 shows the variable definition and operationalization used.

Table 1. Sampling Criteria

\begin{tabular}{lr}
\hline \multicolumn{1}{c}{ Criteria } & Number of samples \\
\hline Manufacturing firms 2013-2018 & 781 \\
\hline Unbalanced samples elimination & $(325)$ \\
No Financial statement & $(42)$ \\
USD currency reporting & $(66)$ \\
Annual report could not be read by & $(6)$ \\
\hline
\end{tabular}


Table 2. Variable Definition and Operationalization

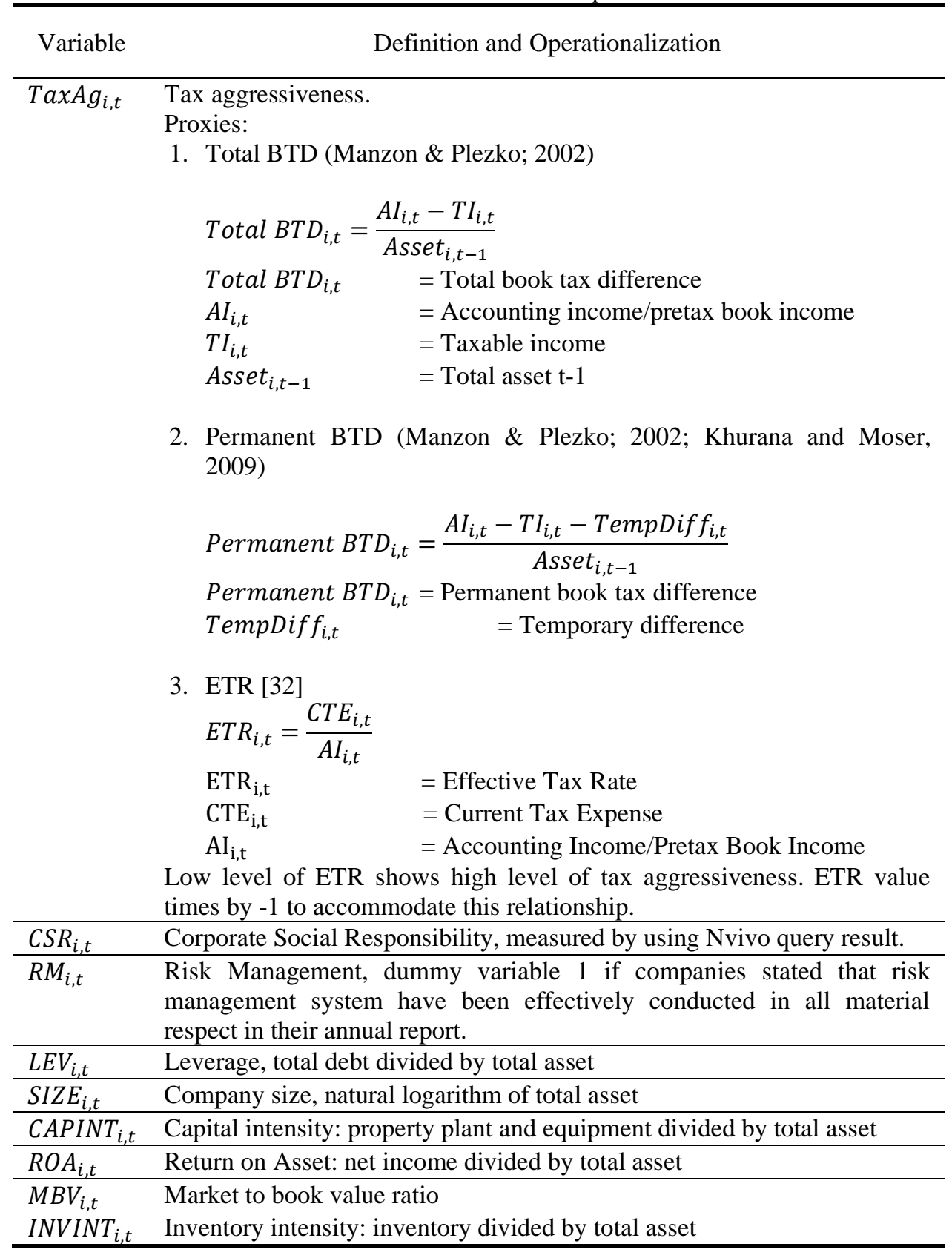




\section{Results and Discussion}

Table 3 shows the descriptive statistic result of the data.

Table 3. Descriptive Statistic Analysis Result

\begin{tabular}{|c|c|c|c|c|}
\hline Variable & Min & Max & Mean & Std. Dev. \\
\hline TaxAg (BTD) & -0.0899 & 0.0994 & 0.0047 & 0.0309 \\
\hline TaxAg (Permanent BTD) & -0.1433 & 0.1597 & 0.0081 & 0.0500 \\
\hline TaxAg (ETR) & -3.4529 & 2.7735 & -0.3937 & 1.0124 \\
\hline CSR & 0 & 0.2566 & 0.0543 & 0.0512 \\
\hline LEV & 0 & 0.6444 & 0.1508 & 0.1637 \\
\hline SIZE & 25.2953 & 33.3415 & 28.5590 & 1.7469 \\
\hline CAPINT & 0.0358 & 1.3983 & 0.4748 & 0.3076 \\
\hline $\mathrm{ROA}$ & -0.1103 & 0.3433 & 0.0794 & 0.0859 \\
\hline MBV & -9.7615 & 16.3374 & 3.1787 & 4.3088 \\
\hline INVINT & 0.0141 & 0.6306 & 0.2156 & 0.1380 \\
\hline Variable & \multicolumn{2}{|c|}{$\begin{array}{l}\% \text { no. of sample with } \\
\text { RM=1 }\end{array}$} & \multicolumn{2}{|c|}{$\begin{array}{l}\text { \% no. of sample with } \\
\text { RM=0 }\end{array}$} \\
\hline RM (dummy variable) & & $39.18 \%$ & & $60.82 \%$ \\
\hline
\end{tabular}

Source: Stata Output, 2020.

The result of classic assumption test shows that the data is normal where the significance value is 0.312 , more than 0.05 . Multicollinearity test shows VIF value $<10$ and tolerance value $>0.01$, so that all independent variables are free from multicollinearity problem. Heteroscedasticity test performed with the White test shows that the data are free from heteroscedasticity problems. Autocorrelation testing proof that the data are free from the autocorrelation problem.

Adjusted R square of 0.442 means that the variation of CSR and risk management as a moderating variable can explain the variation of tax aggressiveness as much as $44.2 \%$, while remains $(55.8 \%)$ are caused by other variables. Table 4 below shows regression result of CSR effect on tax aggressiveness with 3 different proxies: ETR, BTD, and Permanent BTD.

Table 4. Regression Result

\begin{tabular}{lcrrrrrr}
\hline & Proxy & \multicolumn{2}{c}{ ETR } & \multicolumn{2}{c}{ BTD } & \multicolumn{2}{c}{ Permanent BTD } \\
\hline Variables & $\begin{array}{c}\text { Predicted } \\
\text { sign }\end{array}$ & Coef. & Prob. & Coef. & Prob. & Coef. & Prob. \\
\hline CSR & - & -1.101 & 0.263 & -0.058 & 0.112 & -0.777 & 0.155 \\
RM & - & -0.125 & 0.227 & -0.000 & 0.463 & -0.001 & 0.440 \\
CSR RM & $+/$ & 1.457 & $0.098^{*}$ & 0.081 & $0.074 *$ & 0.122 & $0.094^{*}$ \\
LEV & + & -0.250 & $0.010^{* * *}$ & 0.004 & $0.010^{* * *}$ & -0.003 & $0.010^{* * *}$ \\
SIZE & + & 0.326 & $0.000^{* * *}$ & -0.006 & $0.000^{* * *}$ & -0.013 & $0.000^{* * *}$ \\
CAPINT & + & 0.358 & $0.000^{* * *}$ & 0.000 & $0.000^{* * *}$ & -0.002 & $0.000^{* * *}$ \\
ROA & + & -0.251 & $0.000^{* * *}$ & 0.088 & $0.000^{* * *}$ & 0.148 & $0.000^{* * *}$ \\
MBV & - & -0.007 & 0.426 & 0.000 & 0.439 & 0.000 & 0.427 \\
INVINT & - & -0.263 & $0.087 *$ & -0.009 & $0.089 *$ & -0.022 & $0.088^{*}$ \\
N & & & 342 & & 342 & & 342
\end{tabular}




\subsection{The Effect of CSR on Tax Aggressiveness}

Based on table 4 above, we can conclude that CSR do not affect tax aggressiveness. The result shows that there is no significant effect of CSR on tax aggressiveness in these 3 measurements. We can conclude that CSR do not affect tax aggressiveness. This result is inconsistent with corporate culture theory which states that company with high level of CSR will have low level of tax aggressiveness. Corporate culture theory suggests that if the government is also considered as part of stakeholders, then tax aggressiveness should be being inconsistent with CSR activities. Therefore, if corporate culture drives corporate decisions, then socially responsible companies have a low level of tax aggressiveness. This result also not in line with Garriga \& Mele [22], Lanis \& Richardson [8], Bozzolan et al. [24], Col \& Petal [21], Hoi et al. [7], Qodraturrasyid [9], Karthikeyan \& Jain [10], Shafer \& Simmons [11], and Zeng [12].

This result is in line with the research of Wahyudi [14], Wijayanti et al. [15] and Rusydi and Siregar [16]. Companies that have high CSR activity do not necessarily have low level of tax aggressiveness. CSR cannot become an indicator of tax aggressiveness activity. This may happen because companies in Indonesia do CSR activities not driven by corporate culture but only to fulfil government mandatory. This also may happen because CSR activity in Indonesia is still voluntary in action. The company continues to carry out tax aggressiveness despite CSR, especially countries that have transactions in tax haven countries [14][15][16].

\subsection{The Moderation Role of Risk Management in the effect of CSR on Tax Aggressiveness}

Risk management can moderate the effect of CSR on tax aggressiveness. The risk management is proven to strengthen the effect of CSR on tax aggressiveness. Implementation of a comprehensive risk management system makes the quality of CSR reporting and tax obligations fulfilment becomes higher. Companies with more effective risk management systems should tend not to be involved in financial reporting fraud, for example management is not being optimistic by choosing CSR based solely on income tax deduction aspects. The effect of CSR activities in reducing tax aggressiveness is strengthened by the application of effective risk management. The risk management system has a role in moderating the relationship between CSR and tax aggressiveness. This result is in line with the research of Qodraturrasyid [9].

\section{Conclusion}

The result of this study shows that CSR do not affect tax aggressiveness while risk management can moderate the effect of CSR on tax aggressiveness. This study is limited in terms of period observation (2013-2019). The impact in the long run needs to be examined further. CSR is measured using NVivo scoring with keywords generated from GRI G4 guidelines. Others CSR measurement tool such as manual scoring needs to be used to know 
whether it affects the result. Other studies examine the reverse relationship of tax aggressiveness towards CSR and simultaneous relationships among them. These relationships need to be examined further.

\subsection{Funding}

This research is funded by Faculty of Economics Universitas Negeri Semarang.

\section{References}

[1] S. Frank, M., Lynch, L., Rego, "Tax Reporting Aggressiveness and Its Relation to Aggressive Financial Reporting," Account. Rev., vol. 84, pp. 467-496, 2009.

[2] T. Minnick, K.; Noga, "Do corporate governance characteristics influence tax management?," J. Corp. Financ., vol. 16, pp. 703-718, 2010.

[3] G. Lanis, R.; Richardson, "Corporate social responsibility and tax aggressiveness: an empirical analysis," J. Acc. Public Pol., vol. 31, pp. 86-108, 2012.

[4] D. H. Pradipta, "Supriyadi, 2015," Pengaruh Corp. Soc. Responbility, Profitab. Leverage, dan Komis. Indep. terhadap Prakt. Penghindaran Pajak, Makal. Disampaikan dalam SNA XVIII di Medan.

[5] W. A. Tiarawati, "Analisis Pengaruh Pengungkapan Corporate Social Responsibility Terhadap Tax Avoidance (Studi Empiris Pada Perusahaan Manufaktur Yang Terdaftar Di Bei Periode 2009-2013)," J. Akunt. Indones., vol. 4, no. 2, pp. 123-142, 2015.

[6] B. M. Davis, A. K., Guenther, D.A., Krull, L. K., and Williams, "Do socially responsible firms pay more taxes?," Account. Rev., vol. 91, no. 1, pp. 47-68, 2016.

[7] H. Hoi, C.K.; Wu, Q.; Zhang, "Is corporate social responsibility (CSR) associated with tax avoidance? evidence from irresponsible csr activities," Acc. Rev., vol. 88, no. 6, pp. 20252059, 2013.

[8] G. Lanis, R.; Richardson, "Is corporate social responsibility performance associated with tax avoidance?," J. Bus. Ethics, vol. 127, pp. 439-457, 2015.

[9] M. B. R. Qodraturrasyid, "Peran sistem manajemen risiko dalam memoderasi pengaruh aktivitas CSR pada tindakan agresivitas pajak= The role of risk management systems in moderating the effect of CSR activities on tax aggressiveness behaviors," 2017.

[10] B. Karthikeyan, M.; Jain, "Relationship between CSR rating and tax avoidance," IEEE Conf. Comput. Intell. Comput. Res., 2017.

[11] R. Shafer, W.; Simmons, "Social responsibility, Machiavellianism and tax avoidance: A study of Hong Kong tax professionals," Accounting, Audit. Account. J., vol. 21, no. 5, pp. 695-730, 2008.

[12] L. Zeng, S.X.; Meng, X.H.; Yin, H.T.; Tam, C.M.; Sun, "Impact of cleaner production on business performance," J. Clean. Prod., vol. 18, no. 10, pp. 975-983, 2010.

[13] C.-W. Mao, "Effect of Corporate Social Responsibility on Corporate Tax Avoidance: Evidence from a Matching Approach, Quality and Quantity (forthcoming)," 2018.

[14] D. Wahyudi, "Analisis Empiris Pengaruh Aktivitas Corporate Social Responsibility (CSR) terhadap penghindaran pajak di Indonesia," J. Lingk. Widyaiswara, vol. 2, no. 4, pp. 5-17, 2015.

[15] Y. C. Wijayanti, A., Wijayanti, A, Samrotun, "Pengaruh karakteristik perusahaan, GCG, dan CSR terhadap penghindaran pajak," Semin. Nas. IENACO 2016, 2016.

[16] S. V. Rusydi, M.K.; Siregar, "Pengaruh pengungkapan CSR terhadap aggressive tax avoidance," Semin. Nas. Univ. Kristen Maranatha Bandung, 2014.

[17] C. D. Pratiwi, I.S. \& Djakman, "The Role of Corporate Political Connections in the Relation of CSR and Tax Avoidance: Evidence from Indonesia," Rev. Integr. Bus. Econ. Res., vol. 6, no. 1, 2017.

[18] Global Reporting Initiative (GRI), “Sustainability Reporting Guidelines,” vol. 3, no. 1, 2011.

[19] and A. S. Djankov, S., T. Ganser, C. McLiesh, R. Ramalho, "The Effect of Corporate Taxes on 
Investment and Entrepreneurship,"Work. Pap. Natl. Bur. Econ. Res., 2008.

[20] R. W. McGee, "Ethical issues in transfer pricing," Manchester J. Int. Econ. Law, vol. 7, no. 2, pp. 24-41, 2010.

[21] S. Col, B.; Patel, "Going to haven? Corporate social responsibility and tax avoidance," J. Bus. Ethics, vol. 154, pp. 1-18, 2016.

[22] D. Garriga, E.; Mele, "Corporate social responsibility theories: Mapping the territory," J. Bus. Ethics, vol. 53, no. 1/2, pp. 51-71, 2004.

[23] G. Lanis, R.; Richardson, "Corporate social responsibility and tax aggressiveness: a test of legitimacy theory," Accounting, Audit. Account. J., vol. 26, no. 1, pp. 75-100, 2013.

[24] M. G. Bozzolan, S., Fabrizi, M., Mallin C. A., "Corporate Social Responsibility and Earnings Qaulity: International Evidence,” Int. J. Account., vol. 50, pp. 361-396, 2015.

[25] P. Sikka, "Smoke and mirrors: Corporate social responsibility and tax avoidance," Account. Forum, vol. 34, pp. 153-168, 2010.

[26] M. Amidu, T. O. Kwakye, S. Harvey, and M. S. Yorke, "Do firms manage earnings and avoid tax for corporate social responsibility?," 2016.

[27] A. Bebbington, L. Hinojosa, D. H. Bebbington, M. L. Burneo, and X. Warnaars, "Contention and ambiguity: Mining and the possibilities of development," Dev. Change, vol. 39, no. 6, pp. 887-914, 2008.

[28] S. Van der Laan, "The role of theory in explaining motivation for corporate social disclosures: Voluntary disclosures vs 'solicited'disclosures," Australas. Accounting, Bus. Financ. J., vol. 3, no. 4, p. 2, 2009.

[29] U. Landolf, “Tax and corporate responsibility," Int. Tax Rev., vol. 29, no. July, pp. 6-9, 2006.

[30] J. Laguir, I., Staglianò, R., \& Elbaz, "Does corporate social responsibility affect corporate tax aggressiveness?,” J. Clean. Prod., vol. 107, pp. 662-675, 2015.

[31] J. D. Phillips, "Corporate tax-planning effectiveness: The role of compensation-based incentives," Account. Rev., vol. 78, no. 3, pp. 847-874, 2003.

[32] E. Dyreng, S.; Hanlon, M.; Maydew, "Long-run corporate tax avoidance," Account. Rev., vol. 83, no. 1, pp. 61-82, 2008. 